AFRICAN

\title{
Theatre as transcultural capital in the Sino-Nigerian relational context: cultural celebrations at the Confucius Institute in Lagos, Nigeria
}

by Philip Olayoku* Institute for Peace and Strategic Studies/Institute of African Studies University of Ibadan, Nigeria

\begin{abstract}
Studies on Afro-Asian relations have mainly focused on the grand narratives of economic, academic, and diplomatic engagements at the macro level, while discourses on the micro level cultural interactions have been given very little attention. This study, thus, addresses these fault lines by investigating exchanges at this level using the case study of theatre performance at the Confucius Institute in Lagos, Nigeria. The study examined how the use of theatre is integral to the SinoNigerian cultural exchanges by means of the teaching curriculum and cultural celebrations with specific focus on the Spring Festival. The study specifically investigated how performances such as drama, music, dance, martial arts and magic, project the Chinese culture in line with Mao Zedong's and Yoruba functionalist approaches to theatre. It contends that Chinese theatre in Africa serves as an integral cultural component of the Sino-Nigerian economic, diplomatic and academic exchanges while advocating an infusion of a multiculturalist approach to the festival in which both cultures recognize and respect the 'other' in line with Hanban's objective of building a harmonious world.
\end{abstract}

* The author is grateful to Prof. Jiang Lirong, Co Director of the Confucius Institute, who provided access to pictures and video recordings for this research. 


\section{Introduction: theatre as space, people and performance}

Crow (1983: 2) describes the words 'theatre' and 'theatrical' as encapsulating performances beyond drama to include spectacles in public spheres such as cultural activities of coronation, masquerade festivities, ritual performances, public oratory (such as at political rallies) among others. Notable elements within such performances include movement, gesture, voice, costume and physical objects. Thus, beyond the etymology of encapsulating theatre as a space (Greek theatron -'a seeing place'), Crow (1983) describes the usage of the word as inclusive of the profession, 'going into theatre'. Bimbo Benson ${ }^{1}$ (personal communication) corroborates this, positing that theatre can basically be defined as a space in which performance take place. As such, the actors, location and audience are sufficient elements that make up the theatre. Within this broad definitional context, Felner and Orenstein (2006) argued that 'the most essential component of the theatre is the live actor-audience interaction with all its stimulation and surprise which take place across different spaces'.

For Balme (2008: 1), the etymological definition of theatre reflects 'a particular form of sense perception' even as he identified four definitions of the word to show the dynamics of its meaning over time: the building, an activity, an institution and a form of art. Consequently, theatre for our purpose in this discourse is considered as spectacles of performances taking place in different spaces involving actors and the audience. As this study shows, theatrical performances form part of the teaching curriculum and Chinese cultural expressions at the Confucius Institute in Lagos, Nigeria. Such performances are central to the various Sino-Nigerian exchange activities that usually take place within the institute. These activities include the Spring Festival, the Dragon Boat festival, the Mid-Autumn Festival, the Chinese Bridge (a Chinese Proficiency Competition for foreign students) and the Chinese Cultural Month. During these activities, performances cover a range of Balme's (2008) identified forms of theatre to include drama (spoken word performances), music (opera), dance, puppet and mask theatre. Drawing from these forms, theatre has a historical function as it is reflective of realities of the age and place of its 


\section{AFRICAN \\ EAST-ASIAN \\ AFFAIRS

existence (Eni, 2013; Umenyilorah, 2014). The different displays during the Spring Festival, as analysed below, are reflective of this historical continuum with a didactic approach in promoting Chinese language and culture in Nigeria.

Beyond the entertainment and educative functions of theatre, scholars have also emphasised its therapeutic and informative functions (Nasir, 2010; Kamlongera, 2005). Accordingly, theatrical performances advance beyond the passivity of audiences to active interactive modes in the production of cultural meanings. Activities such as the raffle draws taking place intermittently with the presentation of gifts according to various categories engage the audience and are a means of communicating luck and aspirations of good fortune for the new year during the Spring Festival celebrations at the institute. This is representative of the conceptualisation of the performance space as an interactive ambience between the spectators, stage and the environment in which both are located (Balme, 2008). The study focuses on the reinvention of Chinese theatre as part of the engagement of the Confucius Institute with Nigeria at the University of Lagos. The study discusses areas of convergence between Chinese and Nigerian theatre through an overview of their history, nature and functions. It also analyses different modes of performance during the Spring Festival while advocating a multi-culturalist approach for the SinoNigerian relational context (through theatre) in the future.

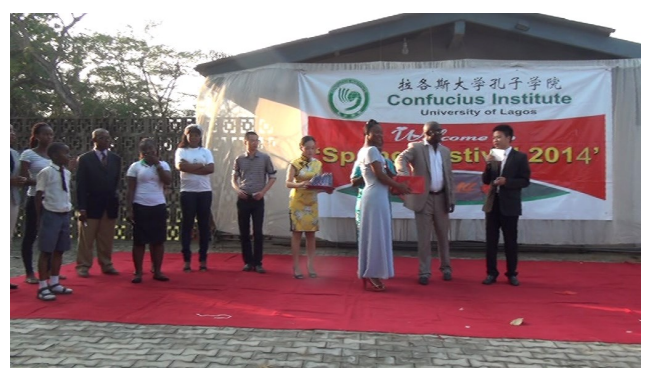

Picture 1. Raffle Draw session during the 2014 Spring Festival 


\section{Functionalist approach to theatre in Nigeria and China}

Within the active interactive mode, theatre can be conceptualised as a sub-cultural eclectic space serving as a melting pot for material and immaterial culture, and it permeates the political, religious, social, educational, health, historical, and recreational institutions (see also Felner and Orenstein, 2006; Mackerras, 2008; Musa 2004; Umenyilorah 2014). This reflects theatre as a space for didactic ideological and character formation as with indigenous African performances (Kamlongera, 2005). In other words, theatre is intrinsic to the lived experience of the African even within its sixth region (Ogom, 2009: 167) ${ }^{2}$ with motifs of cultural traditions sustained in religious modes (Harrison, 2002). It is this interactive mode that makes theatre transformational, as its impact on the audience is sustained beyond the time and space of its performance (Umenyilorah, 2014). One can then easily situate the cultural theatrical performances of the Confucius Institute within such functioning, especially as it engages adults as well as children of different school ages. This function historically aligns with Mao Zedong's approach to theatre during the Cultural Revolution in which performance contents were influenced and censored in an anti-colonialist bid with high emphasis on societal ethos (Mackerras, 2008; Jacovleff and Tchou-Kia-Kien, 1922). The Nigerian example presents theatre as a medium of sensitising and mobilising the people to action against different forms of ills and oppression (Umenyilorah, 2014; Asen, 2015). This dates back to the pre-colonial tradition of correcting and unseating despotic leaders. Suffice to say, like in other parts of Africa (see Article 19, 2003), certain forms of theatre are greeted with suspicion by the government since it has a potential for creating agitations within oppressive polities.

Broadly, within the African world view, theatre is ingrained into the 'daily rituals of life' (Harrison, 2002). Subsequently, theatre as emerging from ritual forms predate written documentation (Felner and Orenstein, 2006; Jacovleff and Tchou-Kia-Kien, 1922), and the African origin of theatre in Egypt has the earliest known forms dating back to the Passion Plays of about 2500 BC (Felner and Orenstein, 2006; Harrison, 2002). Since the African cosmogony exceeds realism into the realm of the spirit, the African theatrical experience is an ensemble of the chanting griot, the accompanying 


\section{AFRICAN \\ EAST-ASIAN \\ AFFAIRS

musicians dictating the different rhythms, and the responding audience ${ }^{3}$ who interplay their roles in creating the ecstatic ambience (Harrison, 2002). Similarly, in Asia, such ambience is created with the location of theatre at local temples (Mackerras, 2009; Felner and Orenstein, 2006). In the Chinese and African theatre traditions (as in others), the interactions between actors and the audience are important for every theatre performance. These performances sometimes involve the wearing of masks which are consecrated by the priests for spiritual potency (Owens, 2014) and Chinese actors also venerate the divinity Lang-lang-pao-sa as the protector of their profession (Jacovleff and Tchou-Kia-Kien, 1922). Masking in both African and Chinese traditions is connected with magic, dance, music and worship. In Africa, Masquerades, at times cult-based, are considered as spirits of the ancestors which are often invoked during ritual dances. In Nigeria, there are different masking purposes whose functions include fertility, initiation, productivity, hunting, war, rituals, and entertainment while the Chinese have masks for sorcery, exorcism, dance, rituals, weddings and funerals (Owens, 2014).

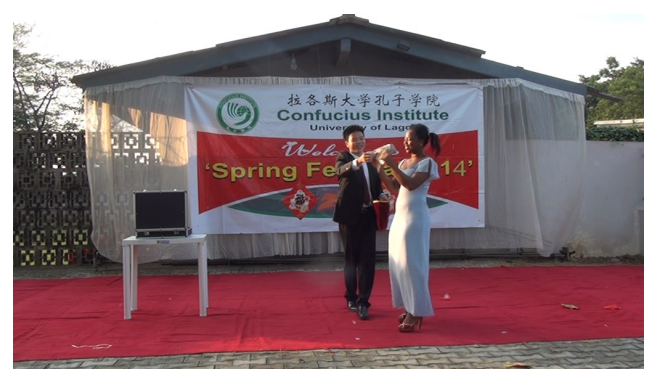

Picture 2. Magic, albeit in a more modernized version, is part of the activities for entertaining guests during the Spring Festival at the Confucius Institute

The ecstatic experiences of magic are replicated in children's theatre which teaches and entertains children by making them create fantasy in their own world based on the realities of the world around them (Daniel-Inim, 2010). The Confucius Institute, 
thus, provides the platform for school children, from the earliest school years through their teenage years, to explore their fantasy through their model schools. The model schools encapsulate both public/private primary and secondary schools who engage in various activities including the Chinese Bridge, the Chinese Dance (fan dance, Zan dance, ballad) Chinese Opera and Chinese Art. These spaces also provide interactive forum with adult engagement and participation as they watch such performances and others by the students of the Confucius Institute in Lagos during cultural festivities.

The earliest stages of performances in life are very crucial to the formation of character in children through adult life as there is a high level of assimilation and retention through participation (Daniel-Inim, 2010). Therefore, the celebration of Chinese culture through theatre fulfils the conventional role of theatre for entertainment and socialisation (Mackerras, 2009). Beyond conventional theatre, there is a high level of interactive modes infused into the teaching and learning process at the Confucius Institute. The students are actively engaged during practical sessions on Chinese paper cut, music, cuisine and Calligraphy.

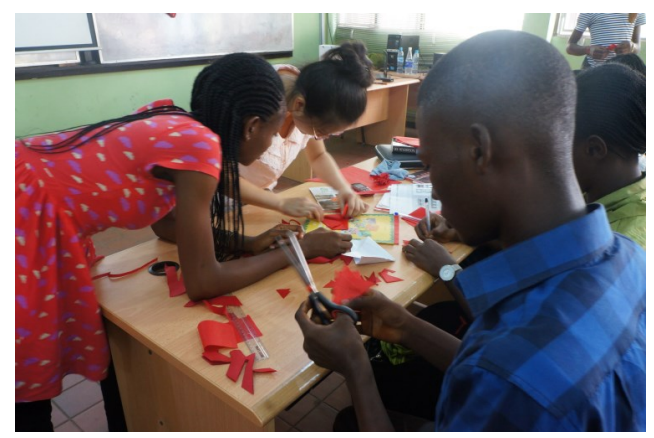

Picture 3. A Chinese Paper Cut Session 


\section{AFRICAN EAST-ASIAN AFFAIRS

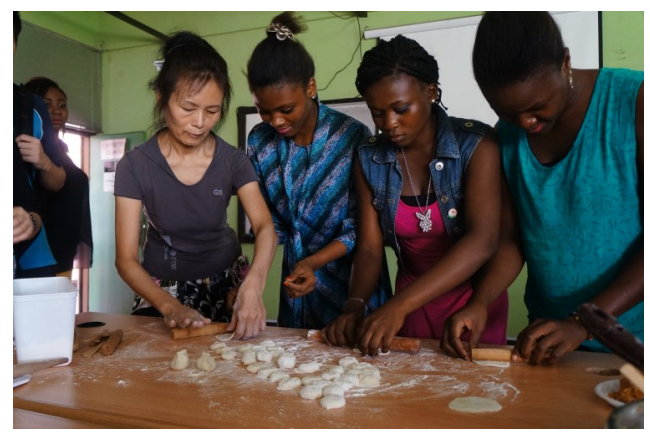

Picture 4. The Co-Director of the Confucius Institute, Professor Lirong Jiang, teaching students how to make the Chinese dumpling

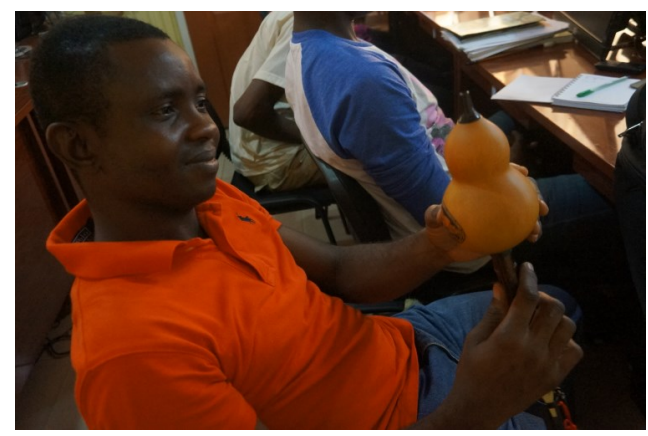

Picture 5. A student at the Confucius institute learning how to play the Hulusi

Such performances also create avenues for escape from unpleasant realities of poor facilities, moral decadence, terrorism, violence and irresponsible parenthood among other societal ills of everyday living experiences in Nigeria (Daniel-Inim, 2010). The sessions present a performance of China to the world as a people who advocate loyalty, peace and high ethical standards as communicated in certain lyrics which encapsulate the teaching content. 


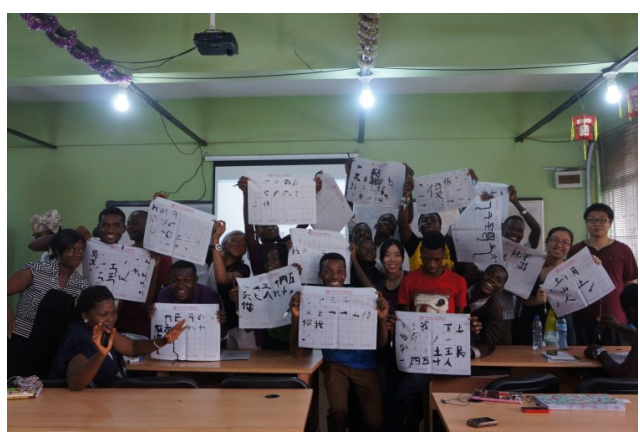

Picture 6. A Chinese calligraphy class

This aligns with the two-fold enduring functions of Chinese theatre; firstly, as entertainment and secondly, as 'a place where the ignorant receive moral instructions' (Jacovleff and Tchou-Kia-Kien, 1922). It also creates an avenue for creating and meeting aspirations as channelled by these experiences. In bridging the Sino-African experiences, it serves the same function as community theatre (Chukwu-Okoronkwo, 2012) whereby alternatives for better living are presented through dance, songs, mimes and other cultural forms. African theatre had been intruded upon by the colonial importation of theatre during which performances were modelled to suit the taste of the colonialists, even as Western models were projected as the universal model (Mollel, 1985; Asen, 2015). This colonial legacy was later to be countered by the resuscitation of traditional models in newly independent African states. The indigenous African models had more social and historical relevance within their contexts of origin (Musa, 2004; Mollel, 1985; Article 19, 2003). Within the globalisation context, the introduction of Chinese theatre to Africa through the Confucius Institute ${ }^{4}$ is, therefore, a cultural complement to the already-blooming economic, diplomatic and academic exchanges, in competition with the West. It is important to note that evidence of cultural exchanges between China and Africa, through arts, (such as painting and graphics) date as far back as the Shang Dynasty (17th - 11th Century BC), while there are even claims of the likelihood of participation of Blacks in government apart from being slaves to the 


\section{AFRICAN \\ EAST-ASIAN \\ AFFAIRS \\ THE CHINA MONITOR}

Chinese. These Blacks are also reported to have taken part in trade, theatre (as actors and musicians), potters, wild animal trainers, porters, guards and peasants ( $\mathrm{Li}$, 2015b). The earliest contacts were likely to be with East Africans (Li, 2015a; Li, 2015b). More so, there is evidence that by 1955, a formal agreement of cultural exchange with Chinese emissaries had been signed with Egypt $^{5}$ paving way for others that have since followed (Mulinda, 2015). Such exchanges are usually facilitated through the establishment of cultural centres abroad by each partner.

\section{The Spring Festival at the Confucius Institute}

The emergence of cultural institutes abroad have been traced to the late 19th Century before the First World War with Italy's Dante Alighieri, Germany's Goethe Institute, Britain's British Council and France's Alliance Francaise playing different but important roles from that period till the present. The layers of engagement across time include cultural nationalism, territorial annexation and protection, cultural propaganda, cultural diplomacy and cultural capitalism (Paschalidis, 2009). The establishment of the Confucius Institute fits into the epoch of cultural capitalism in which there is the commodification of cultural resources, production and experiences (Paschalidis, 2009). The institutes are established through a collaborative funding and support involving Hanban (the state body coordinating all of their activities), a Chinese university and the university of the host country (Hartig, 2012; Zaharna, 2014).

The spread of Confucius Institutes have come under scrutiny based on allegations of political and cultural propaganda due to censorship of the teaching content (avoiding sensitive political issues), and affiliations that give a distorted view of China and its relations. This is regarded by some academics as an infringement on the academic freedom of their host universities, especially in the United States (US) and Canada (Thorpe, 2015; Marcus, 2013). In Africa, the anxiety has been more about neoimperialistic projects of China. China is, thus, suspected by critics as a new imperialist threat to culture and development. Nonetheless, the establishment of Confucius Institutes continues to grow with about 38 institutes and 10 classrooms spread around Africa. ${ }^{6}$ Nigeria has two Confucius Institutes and a language centre. 
The institutes are located at the University of Lagos (UNILAG) and Nnamdi Azikiwe University, Awka, while the language centre is based at the Chinese Embassy in Abuja. The Confucius Institute at UNILAG was initiated in May 2009 through the partnership of the University of Lagos, Hanban and the Beijing Institute of Technology. The centre was established for the teaching of Chinese language and the promotion of friendly economic and cultural exchanges. It is, thus, a meeting point of interactions for Chinese nationals and their Nigerian counterparts especially during cultural celebrations. The cultural exchange is being facilitated through the inclusion of cultural theatre in different activities of the institutes. The activities cover the celebration of the Spring Festival (Chinese New Year), the Chinese Culture Month, the Confucius Institute Day, the Mid-Autumn Festival, and the Dragon Boat Festival. These activities bring together diplomats of different nationalities, school children of different ages, academics, Chinese nationals (mostly teachers and administrators, and Nigerian students.

\section{Theatre at the Spring Festival Celebrations of the Confucius Institute, University of Lagos}

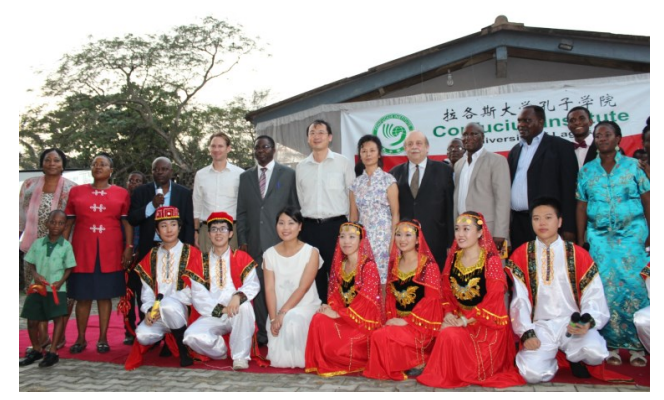

Picture 7. Participants at the 2014 Spring Festival organized by the Confucius Institute $^{7}$ 


\section{AFRICAN \\ EAST-ASIAN \\ AFFAIRS \\ THE CHINA MONITOR}

The cultural theatre at the Confucius Institute represents an alternate community children's theatre with the basic aim of understanding the world in a holistic manner. This is because it provides a bridge between the Asian and African world views through the physical components of dressing, Chinese arts, Chinese people, Chinese food, music and culture which form major components of these celebrations in Nigeria. Far from being unique to the Nigerian theatre experience, scholars in the 20th Century Europe projected the transnational nature of the Asian theatre with Brecht (1964) reflecting the influence of China on the reformation of 'Western Psychological realism' (Balme, 2008). Conversely, Mackerras (2008), elaborating on Chinese huaju (spoken drama), argued that the Chinese theatre has also been influenced by other cultures in the last few decades. Jacovleff and Tchou-Kia-Kien (1922) described the emergence of wen-ming-hi (theatre of civilisation) as an offshoot of western influence. Within the Sino-African scenario, however, it is a convergence of similar practices which characterises the community theatre performance (Mackerras, 2008; Chukwu-Okoronkwo, 2012). This is a trans-cultural mode which has the potential for creating new dynamics in the practice of community theatre in which a national model of development is presented to the other through performance. It is, however, important to point out the need for a symmetrical multi-culturalist approach to such transnational performances in order to maximise the synergy that such theatrical convergence may have on SinoNigerian relations.

One of the performances during the Spring Festival is the elaborate Mongolian Swan goose dance which is a form of ballad that suggests movements of flying geese. The lyrics of the performance are nostalgic and are sung before the toast at dinner by Mongolian people. The song is famous for its 'grand sound, high and melodious tunes' and is descriptive of the Mongolian land and customs'. ${ }^{8}$ Located in Central Area (as a landlocked region between Central and East Asia), this grassland region is situated in the North of China and South of Siberia. The song is performed by an allChinese cast dressed in a red, white and gold Mongolian traditional attire, and long black stockings reaching just below the knees. The lyrics of the songs are quite thematic with the ideas of Unity ('Swan geese in the Sky, fly in Unity'), loyalty 
AFRICAN

EAST-ASIAN

AFFAIRS

THE CHINA MONITOR

('where are they heading for? home is where the heart is'), and hope ('swan geese, coming from the North, take my yearning...').

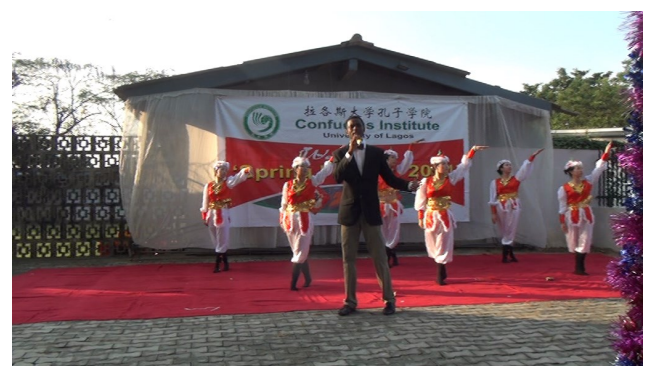

Picture 8. Chinese Mongolian Dance during the 2014 Spring Festival

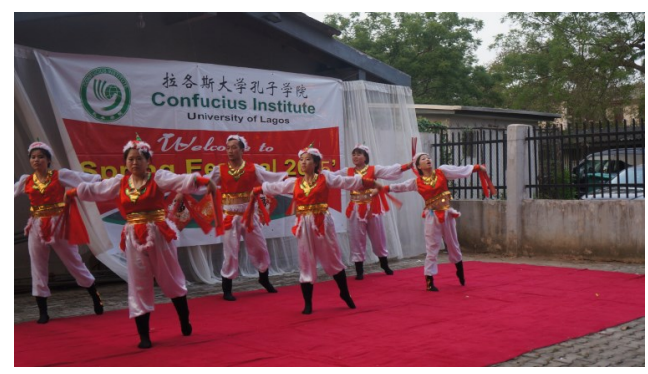

Picture 9. Chinese Mongolian Dance during the 2015 Spring Festival

The accompaniment of instrumental music creates an ambience for nostalgia and allows the audience to relate with the rhythm along the themes of the song. The 2014 edition had an all-female dance group with the song rendered by a Nigerian male singer. The following year, it was a mixed dance group and the song was played from the sound system.

The Xinjiang Uygur folk dance is also one of the traditional dances performed during the Spring Festival. The dance is named after the Uyghurs of Xinjiang, a mountainous autonomous province in China known for their bravery, diligence, 


\section{AFRICAN \\ EAST-ASIAN \\ AFFAIRS

openness and optimism. ${ }^{9}$ The Uyghurs are one of the largest ethnic minorities in China with a significant Islamic population, bordering India, Afghanistan, Pakistan and Central Asia. Worthy of note is the fact that the Uyghur dance has been very important as a tool, adopted by the Chinese Military, in maintaining cordial relations within the restive region. ${ }^{10}$ The dance involves a fast rhythmic movement with a tilted head, thrusted chest, erect waist, shivering of the knees ${ }^{11}$ and elaborate use of the arms. The dance was performed by an all-Chinese male and female cast adorned in the traditional attire of the Uyghurs. The males appear in a white outfit and a red robe and cap, while the females are adorned in an all-red gown and veil. The differences in the regional sources of these performances (the Mongolian and Xinjiang Uyghur dances) are in contrast to the criticism of Confucius Institutes as tools for spreading the propaganda of a mono-cultural China. Also, they are reflective of the historical symbolism of the red and white colour in China. For instance, the use of different colours for the masks in the Chinese Opera signifies different characters. The white mask is used for a disloyal statesman, the red for an upright man and the black mask for a severe and brutal character. Similarly, a parcel that is wrapped in red cloth is said to represent the human head. Any alteration of the traditional forms of make-ups often received hostilities from the spectators (Jacovleff and Tchou-Kia-Kien, 1922).

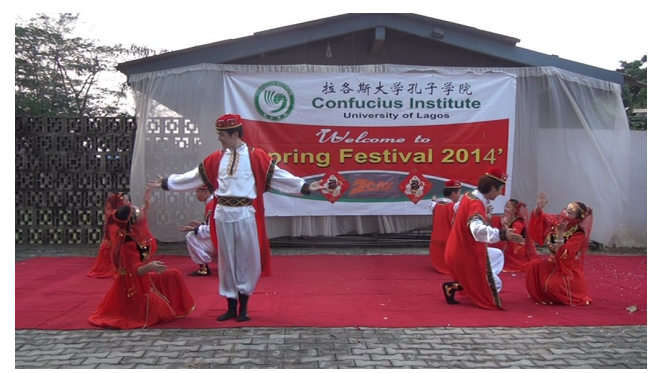

Picture 10. The Xinjiang Uygur dance at the 2014 Spring Festival

It is also pertinent to note that the western influence on Chinese culture is reflected in the Beijing Opera. The opera is performed in a modernised way as they reflect 
western rhythm and dressing during the Spring Festival at the University of Lagos. Similar to this influence is the use of rap music in Mandarin, which reflects a foreign influence and a global culture to which the Nigerian youth audience can relate. ${ }^{12}$ Suffice to say that opera, as a theatre performance, has its variants in the Ijala, Esa, Efe, Egungun and even Ewi traditions in the Yoruba culture. Historically, the Beijing Opera is regarded as a hybrid form evolving from different provinces in China. It gained popularity in 1790 at the 80th birthday and 55th coronation anniversary of Quianlong's Emperor. It is a blend of spoken word, singing, acting, dancing, acrobatics and athletics, usually accompanied by percussion instruments and string fiddles. Hence, its traditional name Pihuang or Lutang which means 'plucking' is in reference to the stringed instruments. ${ }^{13}$ The opera usually involves the use of masks in both traditions dating back to prehistoric times.

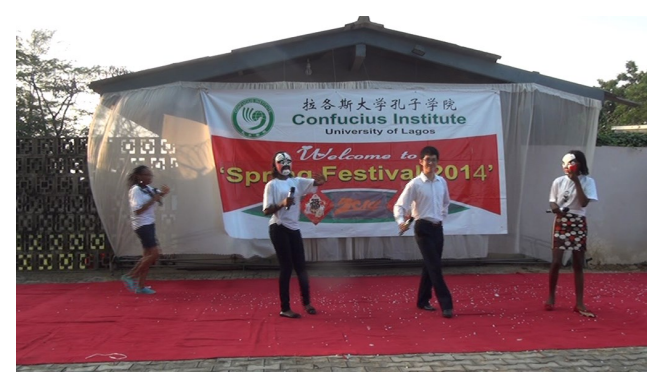

Picture 11. A Chinese Opera performance during the 2014 Spring Festival

The masking traditions were spiritual exercises in which performances had lots of implication for societal ethos. Masks were either worn over the face or as covers for the entire body (Owens, 2014). The Beijing Opera, as in other theatres, involves five traditional characters namely sheng (male), dan (female), jing (the male masked face), chou (the clown) and Mo (an old male character) ${ }^{14}$ (Jacovleff and Tchou-KiaKien, 1922). The Chinese theatre was not without its challenges as actors were usually of low social status while Aristocrats between the 15th and 19th Centuries undermined it. Women were prevented from acting (on moral grounds) as young men played their roles (Mackerras, 2009; Jacovleff and Tchou-Kia-Kien, 1922). ${ }^{15}$ 


\section{AFRICAN \\ EAST-ASIAN \\ AFFAIRS

Race and gender are also mainstreamed during cultural celebrations at the institute. There is an interchange of the role plays of presenters who mainly comprise of both male and female Nigerian and Chinese nationals with equal representation. These presenters take their turns in introducing the presentations in both English and Mandarin. This is in contrast to the imposed patriarchal superiority of Western religion and culture, which subsumed the hitherto dominant and complementary female gender roles within the African experience (Soyinka, 1976; Harrison, 2002). As a matter of fact, the two directors (a Nigerian male and Chinese female) reflect this during the introduction and welcoming of guests to the programmes. This is not just coincidental as Mackerras (2008) argued that theatre was a tool for gender mainstreaming in 20th Century China. The bridging of racial and gender gaps is a symbolic interactive function of the cultural performances at the Confucius Institute in Lagos. More so, since theatre had transformed from a lower status to a higher social status within both societies (Mackerras, 2009; Jacovleff and Tchou-Kia-Kien, 1922; Akashoro, Kayode and Husseini, 2010), its potential to influence the audience beyond the location of performance cannot be ignored.

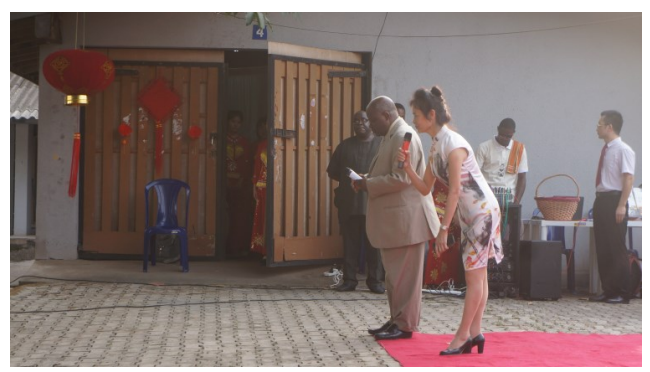

Picture 12. The directors of the Institute, Professors Awonusi and Jiang hosting the introductory section of the 2015 Spring Festival Celebration 


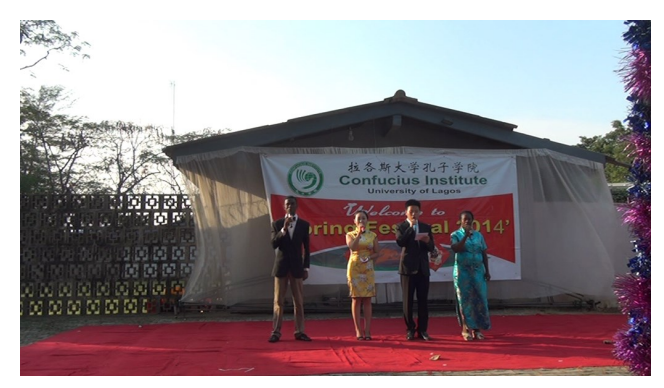

Picture 13. Nigerian and Chinese hosts during the 2014 Spring Festival

Musa (2004) described the Nigerian theatre as a multi-cultural space, encapsulating the different segments of architecture, management, actors, institutions, activities and even play-texts. Its central theme has been to entertain and educate the Nigerian audience in advancing the principle of unity in diversity (Musa, 2004: 71). The celebration of the Spring Festival creates an avenue for expressing this multiculturalist solidarity with the Chinese through theatre. Within this transnationality, an all-Nigerian cast is introduced to the audience to perform a song about the Chinese people. Dressed in western outfits, the performers come on stage with a Chinese flag in hand as they entertain the audience with the song 'The Chinese' in Mandarin.

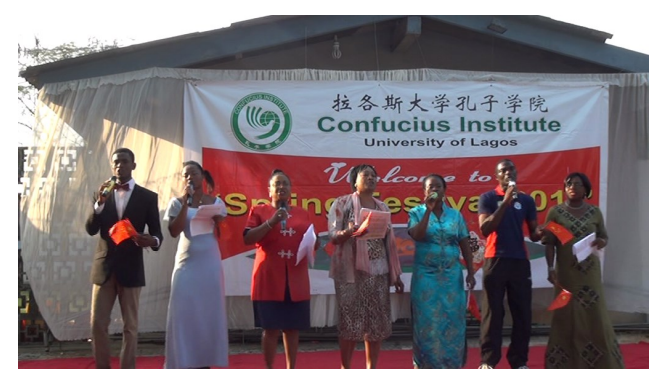

Picture 14. Nigerian students and staff of the Confucius Institute rendering the song 'The Chinese' at the 2014 Spring Festival 
AFRICAN

EAST-ASIAN

AFFAIRS

The song is about the history of the Chinese people spanning over 5, 000 years with their physical identity revealed as a people of 'yellow eyes, black eyes and ever smiling faces'. More importantly, the theme of hope, unity, and progress in adversity runs through the lyrics, part of which goes thus:

No matter where you have come from

Or where you will be going

The same tear, the same pain,

Tribulations once endured

Will remain in our hearts

The same blood, the same ethnic

Dreams for the future

We shall pioneer together

Hand in hand, regardless of you and me

Heads up high, walking forward

Let the world know

We are Chinese

The above lyrics can be thematically likened to a line in the former Nigerian national anthem which states that 'though tribes and tongues may differ, in brotherhood we stand'; more specifically, in its focus on unity in diversity. Its didactic nature is apt as it presents a multi-ethnic scenario which focuses on progress irrespective of differences. The audience, thus, can relate with the multi-ethnic experiences and how to turn diversity into strength. At the end of the performance, shouts from the audience commending the performance can be heard. A Chinese audience member remarked 'That's good! Good a job!!!'

The Chinese martial arts are among the prominent and earliest cultural exploits of China to Nigeria. Also known as kung fu or wushu, they include different fighting styles developed by different Chinese schools across centuries. In line with this, the mid-20th Century witnessed a rise in the presence of Chinese theatre and television in the country. While the Ahmadu Bello University in Zaria (in Northern Nigeria) screened some Chinese theatre including 'The East is Red' (self-directed by Mao 
Zedong), ${ }^{16}$ the television houses screened many Chinese movies from popular martial arts actors and actresses such as Bruce Lee, Jackie Chan, Li Gong, Jet Li, Leslie Cheung and Ziyi Zhang. The Confucius Institute, therefore, integrates this aspect of Chinese culture into its teaching curriculum and theatre. The particular performance displayed at the institute is known as the taiji quan modelled after the Taiji Chinese. The show involves the Chinese teachers and their students briefly displaying their dexterity and competence in the arts. Martial arts have been imbibed as a medium for exercise among children, youth and young adults in Nigeria. Most martial arts schools have different grades of students who are identified by the colours of their belt which are usually white, orange, green, brown, and black. The schools are usually domiciled in different stadia, private gyms and university environments across Nigeria. They often have practice sessions on weekends, usually Saturdays.

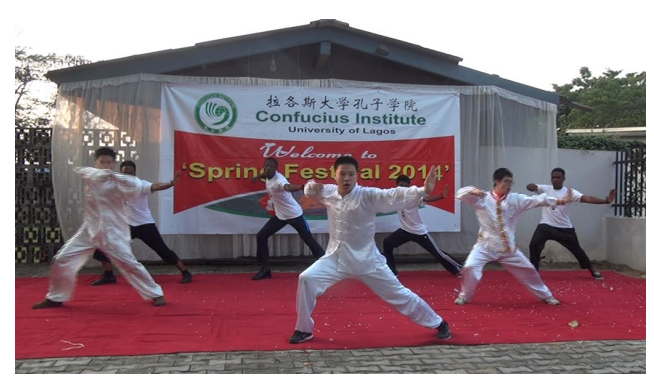

Picture 15. Martial Arts show during the 2014 Spring Festival 


\section{AFRICAN EAST-ASIAN AFFAIRS

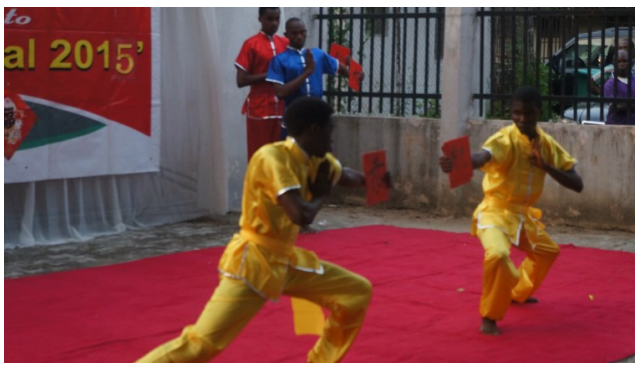

Picture 16. Martial Arts show during the 2015 Spring Festival

The Spring Festival is usually rounded off by the performance of the song 'Wish you good Fortune' led by Professor Lirong Jiang, the Chinese director of the Confucius Institute. The performance is used to pass the message of wishing away ill fortune and ushering in good luck in the New Year. The year 2015 was The Year of the Ram, the animal which represents the eighth sign of the Chinese Zodiac. It is, thus, a year with promise and prosperity; and those born in the year are projected to be kind, helpful, trusting and peaceful, just like the ram (Choy, 2015). All the previous performers are invited to the stage at a point bearing Chinese signs and symbols that project good fortune as they wish everyone the best in the New Year.

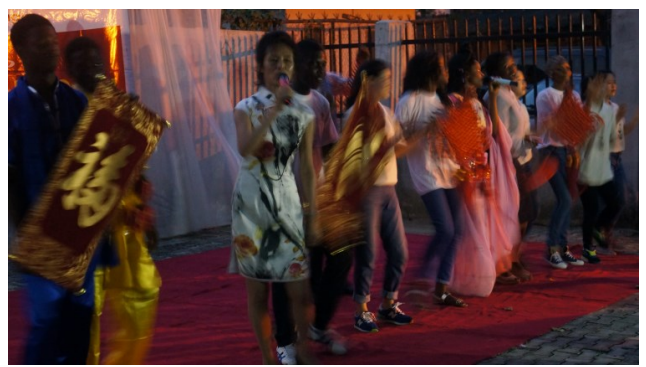

Picture 17. The Chinese Co-Director, Professor Jiang, leading the performance of the song 'Wish you Good Fortune at the 2015 Spring Festival 


\section{Conclusion}

For Musa (2004), inter-culturalism bridges the gap between two cultures, which could be national or international. Nevertheless, of primary importance is the need for a symbiotic rather than parasitic cultural interaction, as the latter eventually results in the annihilation of a culture to the detriment of its adherents. The intercultural context is one that is suitable for the Sino-Nigerian relational context especially during cultural exchanges as shown in the example of the Confucius Institute above. Thus, rather than a cultural imperialist mode where a culture seeks to negate and dominate other cultures (as was with the Western introduction of theatre to Africa) (see Harrison, 2002; Kamlongera, 2005), a multi-culturalist approach is one that recognises and respects the 'other' and its unique features. This is in line with one of the objectives of Hanban stated as: meeting the demands of foreign Chinese learners and contributing to the development of multi-culturalism and the building of a harmonious world. ${ }^{17}$

In the age of globalisation, societal developments have been enhanced through interculturalism, even if such exchanges have often been asymmetrical. Nonetheless, theatre, as a tool for societal development, ought to be dynamic since it functions to educate, entertain and engineer social progress (Musa, 2004; Article 19, 2003). The Sino-Nigerian relational context has been one of mutual trans-culturality; in which cultural capital is exported across both spaces with the examples of the establishment of Confucius Institutes and language centres in Nigeria, and the reciprocal establishment of the Nigerian cultural centre in Beijing in the year 2012 (Mason, 2014). Within this transcultural context of exchange, hybrid models of cultural and theatre forms are beginning to emerge especially in terms of linguistic modes, and the motifs of theatrical contents and expressions. A growing trend and a reflection of these possibilities is the emergence of Nigerian artists based in China who perform in Mandarin. Notable Nigerian musicians in China include Uwechue Emmanuel (Hao Ge), Mr Lo D and Dibaocha Sky, while other popular musicians like KCEE, Faze and Oritsefemi ${ }^{18}$ have performed and shot videos in China. Other forms of art have also been employed by Ajike (Ejike) Njoku, whose photography, paintings and literary works are based on how Nigerians and the Chinese perceive one another in a 


\section{AFRICAN \\ EAST-ASIAN \\ AFFAIRS \\ THE CHINA MONITOR}

bid to promote tolerance and harmony (Peters, 2014).

However, there is the potential for endangerment of cultural patterns where there is irregularity in the cultural content of such hybridity. Scholars like Bodomo (2009) and Zhang (2016) have, thus, advocated the need for symmetry within Sino-African partnerships and relational context. Within the Nigerian cultural space, there is already the agitation, in both formal and informal spaces, around the allegations of cultural propaganda of the Chinese as neo-imperialists using the Confucius Institute as a soft landing tool. With a history of adopting theatre as a mode of nationalistic propaganda in China's anti-colonial war under Mao Zedong (Mackerras, 2008), the establishment of a Nigerian Cultural centre in Beijing mentioned earlier is a crucial step in aspiring towards a symmetrical relationship. The cultural centre is the first African Cultural Centre to be established in China's Capital in the year 2011 and there were subsequent Nigerian cultural week celebrations in Beijing and Nanjing Provinces in 2012 and 2013 respectively. The cultural displays included performances by the National Troupe of Nigeria, two Nigerian cultural troupes (from Bayelsa and Kwara States), and there were exhibitions of Nigerian cuisine, fashion and arts by the National Council for Arts and Culture (NCAC), Centre for Black African Arts and Civilization (CBAAC) National Gallery of Arts, the National Institute for Hospitality and Tourism, and the National Commission for Museums and Monuments. Hao Ge and China's Little Red Flower Troupe were also performers at the events (see Udeze, 2012; Oladokun, 2013).

Within Nigeria, however, the foreseeable future may entail a mixed performance of indigenous theatre such as the Ijala, Esa, Efe, Egungun, and Ewi alongside Chinese opera, folk dance, kung fu, and magic within the same spaces for entertainment. Such collaborations have been spearheaded by the NCAC and the Chinese Cultural Centre (CCC) through the Chinese-Nigerian Evening of Cultural entertainment in Abuja wherein both Nigerian and Chinese cultural troupes performed dance drama, music, and poetry (Onochie, 2015). Within the present context of technological advancement and preference for electronic means of communication, the SinoNigeria cultural exchange can also assume virtual forms. Such a mediation of theatre by technology may result in performances in Nigeria being screened to Chinese 
audiences abroad and vice versa. This, in a way, fits into the realist perception of theatre as audiences would better relate with these performances when they are carried out in their natural spaces.

\section{Endnotes}

1. Bimbo Benson is a lecturer at the Theatre Arts Department, University of Ibadan (Personal Communication on 17 June, 2015).

2. The incorporation of the Diaspora as the sixth Region of the African Continent was a major focus of the 2012 Global African Diaspora Summit. The Programme of Action A (k) of the declaration reads, thus, 'Encourage the Diaspora to organize themselves in regional networks and establish appropriate mechanisms that will enable their increasing participation in the affairs of the African Union as observers and eventually, in the future, as a sixth region of the continent that would contribute substantially to the implementation of policies and programmes'.

3. The audience emerged from specialisations (of emerging playwright, actors and audience) in theatre. Felner and Orenstein (2006) argued that the earliest audiences were the invisible divinities as everyone present participated in ritual performances.

4. The Confucius Institute at the University of Johannesburg is exploring other art forms by holding art exhibitions of a documentary portrait on Mandela by the Chinese painter, Li Bin. See http://fadagallery.blogspot.com.ng/search? updated-max=2015-09-12T02:09:00-07:00\&max-results $=7$.

5. The earliest mentions of African countries included places in Egypt and Ethiopia amongst other locations in East Africa. The Arabs are reported to have facilitated these early contacts as blacks formed part of their trade entourage (see Li, 2015a; Li 2015b).

6. See http://english.hanban.org/node_10971.htm.

7. They include the Chinese consul, French Consul (an expert in Chinese Studies), Directors of the institute, Chinese teachers and the students. 


\section{AFRICAN

8. See http://www.chinesecio.com/m/pages/view/Mongolian-folk-song-Swangoose- $\%$ E8\%92\%99\%E5\%8F\%A4\%E6\%B0\%91\%E6\%AD\%8C-\%E9\%B8\% ВF\%Е9\%9B\%81.

9. See Uygur Dances - Chinese Folk Dances of Xinjiang http://arts.culturalchina.com/en/96Arts10377.html.

10. See China's military in restive Xinjiang told to learn Uygur folk songs and dances. South China Morning Post. Retrieved from http://www.scmp.com/ news/china/diplomacy-defence/article/1858710/chinas-military-restivexinjiang-told-learn-uygur-folk.

11. See http://www.huangshantour.com/english/SmallClass.asp? typeid $=28 \&$ BigClassID $=66 \&$ smallclassid $=210$

12. Nigerian pop artists are recently making waves in China. Their music is either sung in Mandarin or a code mixing of Mandarin and English Language. One of such artists is Emmanuel Uwechue, with an adopted Chinese name Hao Ge which means 'good song'.

13. See The Cleveland Museum of Art. Theater in China and Japan: A Look at the Beijing Opera and the Kabuki theatre. Unpublished.

14. Ibid.

15. According to Jacovleff and Tchou-Kia-Kien (1922), women were banned from theatre until the 20th Century after Emperor K'ien-Long took one of the actresses as a concubine. As such, men and women did not perform together during this period.

16. Personal Communication with Prof James Gibbs via E-mail Correspondence on 9 April, 2015.

17. See http://english.hanban.org/node_7719.htm.

18. See https://africansinchina.net/tag/nigerians-in-china/. 
AFRICAN

EAST-ASIAN

AFFAIRS

THE CHINA MONITOR

\section{Bibliography}

Article 19. 2003. Women's Voices and African Theatre: Case Studies from Kenya, Mali, the Democratic Republic of Congo and Zimbabwe. Braamfontein: Article 19.

Akashoro, Olalekan, Jimi, Kayode and Shaibu, Husseini. 2010. Theatre and Development: Opportunities and Challenges in a Developing World. Journal of Communication, 1(2):107-112.

Asen, Marcellinus. 2015. Radical Theatre in Contemporary Nigeria: A Review of the Contributions of Saint Gbileeka. International Journal of Language, Literature and Gender Studies, 4(1):128-136.

Balme, Christopher. 2008. The Cambridge Introduction to Theatre Studies. Cambridge: Cambridge University Press.

Bodomo, Adams. 2009. Africa-China Relations: Symmetry, Soft Power, and South Africa. China Review, 9(2):169 - 178.

Chukwu-Okoronkwo, Samuel. 2012. Trends in the Development of Alternative Theatre Practice: The Ahmadu Bello University, Zaria, Nigeria Example. Academic Research International, 2(3):682-689.

Crow, Brian. 1983. Studying Drama. Ibadan: Longman.

Daniel-Inim, Praise. 2010. Community Children's Theatre at Igbinedion University, Okada. Ibadan Journal of Theatre Arts, 5 \& 6: 82-94.

Declaration of the Global African Diaspora Summit Sandton, Johannesburg, South Africa 25 May 2012.

Eni, Kenneth. 2013. Aesthetic Considerations in Contemporary Nigerian Theatre Design and Technology. Online International Journal of Arts and Humanities, 2(5):157-165.

Felner, Mira and Orenstein, Claudia. 2006. The World of Theatre: Tradition and Innovation. Boston: Allyn \& Bacon. 


\section{AFRICAN \\ EAST-ASIAN \\ AFFAIRS \\ THE CHINA MONITOR}

Harrison, Paul. 2002. Praise / Word, in Paul Harrison, Victor Leo Walker and Gus Edwards (eds). Black Theatre: Ritual Performance in the African Diaspora. Philadelphia: Temple University Press. 1-17.

Hartig, Falk. 2012. Confucius Institutes and the Rise of China. Journal of Chinese Political Science 17:53-76.

Jacovleff, Alexandre and Tchou-Kia-Kien. 1922. The Chinese Theatre. James Graham (tr.). London: John Lane the Bodley Head.

Kamlongera, Christopher. 2005. Theatre for Development in Africa, in Oscar Hemer and Thomas Tufte (eds). Media \& Glocal Change: Rethinking Communication for Development. Buenos Aires: CLACSO. 435-452.

Li, Anshan. 2015. Contact between China and Africa before Vasco da Gama: Archaeology, Document and Historiography. World History Studies, 2(1):3459.

Li, Anshan, 2015. African Diaspora in China: Reality, Research and Reflection. The Journal of Pan African Studies, 7(10):10-43.

Mackerras, Collin. 2008. Tradition, Change, and Continuity in Chinese Theatre in the Last Hundred Years: In Commemoration of the Spoken Drama Centenary. Asian Theatre Journal, 25(1):1-23.

Mackerras, Collin. 2009. Chinese and Western Drama Traditions: A Comparative Perspective, in Paul Gladston (ed). China and Other Spaces: Selected Essays by Contributors to the Research Seminar Series of the Institute of Comparative Cultural Studies at the University of Nottingham, Ningbo, China, 2005-2007. Nottingham: Critical, Cultural and Communications Press. 21-34.

Mason, Lucy. 2014. Nigeria and China Discuss Cultural and Tourism Ties. Fascinating Nigeria, June $8 . \quad$ [Online] Available: www.fascinatingnigeriamagazine.com/2014/07/nigeria-and-china-discusscultural-and-tourism-ties/. [Accessed: 9 August 2016].

Marcus, Jon. 2015. West's Universities reconsider China-funded Confucius 
AFRICAN

EAST-ASIAN

AFFAIRS

THE CHINA MONITOR

Institutes. [Online]. Available: www.timeshighereducation.com/news/westsuniversities-reconsider-china-funded-confucius-institutes/2002870.article.

[Accessed: 2 December 2015].

Mollel, Tololwa. 1985. African Theatre and the Colonial Legacy: Review of the East African Scene. Utafiti, 7(1):20-29.

Mulinda, Charles. 2015. On Cultural and Academic Exchanges between China and African Countries. International Journal of Asian Social Science, 5(4):245-256.

Musa, Rasheed. 2004. Multiculturalism and the Dialectics of Ethnic Images in the Nigerian Theatre. The Performer, 6:63-82.

Nasir, Taofeek. 2010. Drama as an Exploratory Paradigm in Lock-Up Institutions. Ibadan Journal of Theatre Arts, 5 \& 6:137- 154.

Ogom, Raphael. 2009. The African Union, African Diasporas and the Quest for Development: In Search of the Missing Link. African Journal of Political Science and International Relations, 3 (4):165-173.

Oladokun, Taiwo. 2013. Nigerian Culture is Toast of China. The Nation. [Online]. Available: http://thenationonlineng.net/nigerian-culture-toast-china/. [Accessed: 9 August 2016].

Onochie, Bridget. 2015. When Nigeria, China Celebrate Cultural Ties. [Online]. Available: http://guardian.ng/art/when-nigeria-china-celebrate-cultural-ties/. [Accessed: 9 August 2016].

Owens, Ida. 2014. The Mask Making Traditions, Functions and Global Connections among China, Africa and India. Unpublished Fulbright-Hays Seminars Abroad to China Paper. [Online]. Available: http://www.ncuscr.org/sites/default/files/ Ida-Owens-Final.pdf [Accessed: 27 April 2015].

Paschalidis, Gregory. 2009. Exporting National Culture: Histories of Cultural Institutes Abroad. International Journal of Cultural Policy, 15(3):275-289. 
AFRICAN

Peters, Mike. 2014. Cross-cultural Interactions. China Daily, [Online]. Available: http://www.chinadaily.com.cn/culture/art/2014-02/16/content_17285328.htm. [Accessed: 8 August 2016].

Soyinka, Wole. 1976. Myth, Literature and the African World. New York: Cambridge University Press.

Thorpe, Becca. 2015. The Future of Confucius Institutes in the US Pulitzer Centre on Crises Reporting. [Online]. Available www.pulitzercentre.org/reporting/ united-states-china-confucius-institutes-academic-freedom-culture-sharpseminar. [Accessed: 2 December 2015].

Udeze, Edozie. 2012. Nigerian Dancers Dazzle in Beijing, China. The Nation. [Online]. Available: http://thenationonlineng.net/nigerian-dancers-dazzle-inbeijing-china/. [Accessed: 9 August 2016].

Umenyilorah, Chukwukelue. 2014. Theatre as Tool for Development in Nigeria. IOSR Journal of Humanities and Social Science, 19(60): 34-40.

Zaharna, Rhonda. 2014. China's Confucius Institutes: Understanding the Relational Structure \& Relational Dynamics of Network Collaboration, in Rhonda Zaharna, Jennifer Hubbert and Falk Hartig (Co-Authors). Confucius Institutes and the Globalization of China's Soft Power. Los Angeles: Figueroa Press. 


AFRICAN
EAST-ASIAN
AFFAIRS

